\title{
Wątpliwości wokół instytucji Rzecznika Praw Podatnika
}

\author{
Doubts about an institution \\ of the Taxpayer's Rights Ombudsman
}

Streszczenie. Ombudsman (inaczej rzecznik) to określenie pochodzące z języka szwedzkiego, określające niezależnego urzędnika, do którego można się zwrócić po wyczerpaniu wszystkich środków odwoławczych przewidzianych prawem lub w przypadku naruszenia podstawowych zasad, dla których nie uwzględniono środków zaskarżenia. Projekt ustawy powołujący instytucję Rzecznika Praw Podatnika (dalej: RPP) zakłada pomaganie obywatelom w sprawach podatkowych. Instytucja ta będzie miała charakter struktury terenowej, a mianowicie delegatura urzędu ma być usytuowana w każdej z szesnastu izb administracji skarbowej w Polsce, natomiast siedziba główna ma znaleźć się w Warszawie. Podatnicy mają mieć zapewniony dostęp do Rzecznika na terenie całego państwa, a nie tylko w stolicy. Osoba piastująca funkcję RPP będzie musiała spełnić szereg warunków, m.in. mieć 10-letnie doświadczenie w praktyce stosowania prawa (jego zastępcy 5-letnie). Pierwsza część artykułu dotyczyć będzie zakresu obowiązków, jakie przyznano RPP, m.in. omówiono funkcję interwencyjną, czyli 
udział w toczących się postępowaniach, możliwość wnoszenia odwołania i skargi do sądu. RPP będzie miał także możliwość prowadzenia procedury mediacyjnej przewidzianej w nowej Ordynacji podatkowej. W drugiej części artykułu podjęta zostanie próba udzielenia odpowiedzi na następujące pytania: czy i w jaki sposób RPP będzie wspierał przedsiębiorców i samorządy zawodowe? Czy będzie to instytucja neutralna? Zakłada się, iż RPP będzie powoływany przez Prezesa Rady Ministrów na 6-letnią kadencję, na wniosek Ministra Finansów. Na koniec przedstawione zostaną dane liczbowe - jaki ma być koszt utworzenia i utrzymania nowej instytucji. Artykuł przygotowany został na podstawie projektu ustawy o RPP, projekt nr UD421 ${ }^{1}$, oraz oficjalnych publikacji Ministerstwa Finansów $(\text { dalej: } M F)^{23}$.

Słowa kluczowe: podatki; rzecznik; administracja skarbowa; skarga.

Abstract. A public advocate (also called "an ombudsman") is a term derived from the Swedish language, which defines it as an independent official to whom one can appeal after exhausting legal remedies. According to the draft of law, the public advocate's primary role will be helping citizens in tax issues. This institution will be territorially decentralized, namely the office will be located in each of the sixteen tax chambers in Poland, the headquarters will be located in Warsaw. Taxpayers will have an access to the Ombudsman throughout the country, not only in the capital. The Taxpayer's Ombudsman will have to have 10 years of practice of applying the law and his deputies -5 years of the practical experience. The first part of the article will deal with the scope of the duties assigned to the Tax Ombudsman. The interventionist function will be discussed: participation in ongoing proceedings, as well as a possibility of lodging appeals and complaints to the court. The Taxpayer's Ombudsman will also be able to conduct the mediation procedure envisaged in the tax code. The second part of the article will take an attempt to give an answer to the following question: whether and how the Taxpayer's Ombudsman will support the entrepreneurs and the professional selfgovernments? Will it be a neutral institution? It is assumed that the Taxpayer's Rights Ombudsman will be appointed by the Prime Minister for a 6-year term and

1 Rządowy projekt ustawy o Rzeczniku Praw Podatnika, VIII kadencja, nr projektu: UD421, bip.kprm.gov.pl, (dostęp: 8.04.2019 r.).

2 Ministerstwo Finansów, Uzasadnienie ustawy o Rzeczniku Praw Podatnika, Warszawa 2018, s. 1.

3 Kancelaria Prezesa Rady Ministrów, Wykaz prac legislacyjnych i programowych Rady Ministrów: Projekt ustawy o Rzeczniku Praw Podatnika, Warszawa 2019, s. 1. 
designated by the minister responsible for the public finance - presuming that it will be difficult for the Ombudsman to maintain impartiality. In, the end, data will be presented - how much creation and maintaining of this institution will cost. The article was prepared on the basis of Taxpayers' Ombudsman draft act No UD421 ${ }^{4}$ and official publications of the Ministry of Finance ${ }^{56}$.

Keywords: tax; ombudsman; tax administration; complaint.

\section{Wprowadzenie}

Celem artykułu jest ocena, czy RPP jest potrzebny w polskim porządku prawnym oraz czy nowa instytucja będzie skutecznie realizowała swoje główne zadanie, jakim jest ochrona praw wszystkich podatników. Tak postawiony cel pracy determinuje przyjęcie odpowiedniej metodologii, która została oparta na metodzie dogmatycznej - tradycyjnie wykorzystywanej w pracach naukowych z zakresu prawa.

Rzecznik Praw Obywatelskich (dalej: RPO) jest instytucją niezależną, tzn. jest odseparowany od sądownictwa i administracji. Powiązany jest jednak z władzą ustawodawczą poprzez sposób powoływania oraz kontrolną funkcję sprawowaną przez Sejm. Rola RPO polega na reagowaniu w przypadku, gdy naruszone zostaną prawa i wolności obywatelskie. Posiada on również możliwość podejmowania działań z własnej inicjatywy. Ponadto może wybrać jeden z trzech trybów postępowania, tzn. samodzielnie prowadzić postępowanie wyjaśniające, skierować sprawę do zbadania przez organy nadzoru bądź zwrócić się do Sejmu o zalecenie weryfikacji Najwyższej Izbie Kontroli. Prowadząc postępowanie, RPO ma prawo zbadać kwestię na miejscu, zażądać złożenia wyjaśnień i przedstawienia akt każdej sprawy prowadzonej przez organy administracji państwowej, organizacje społeczne, samorządowe, osoby prawne itd. Może

4 Rządowy projekt ustawy o Rzeczniku Praw Podatnika, VIII kadencja, nr projektu: UD421, bip.kprm.gov.pl, (dostęp: 8.04.2019 r.).

5 Ministerstwo Finansów, Uzasadnienie ustawy o Rzeczniku Praw Podatnika, Warszawa 2018, s. 1.

6 Kancelaria Prezesa Rady Ministrów, Wykaz prac legislacyjnych i programowych Rady Ministrów: Projekt ustawy o Rzeczniku Praw Podatnika, Warszawa 2019, s. 1. 
występować do właściwych organów z wnioskiem o podjęcie odpowiedniej inicjatywy ustawodawczej bądź wydanie lub zmianę aktów prawnych niższych niż ustawa. Ponadto może zwrócić się do Trybunału Konstytucyjnego o uznanie aktu normatywnego lub przepisu za sprzeczny z Konstytucją ${ }^{7}$. Kontakty RPO z osobami fizycznymi mają charakter nieformalny, bowiem ustawa nie reguluje procedury rozstrzygania spraw dotyczących bezpośrednio obywateli Rzeczypospolitej Polskiej.

W Polsce mamy dwóch rzeczników ustanowionych w Konstytucji RP. Są to: RPO (organ ustanowiony w 1987 r., powoływany przez Sejm), Rzecznik Praw Dziecka (organ ustanowiony w 2000 r. i wybierany przez Sejm). Inne obecnie istniejące urzędy rzeczników to: Rzecznik Konsumentów (instytucja ustanowiona w 1999 r.; wybierany przez starostę lub prezydenta miasta), Rzecznik Finansowy (wcześniej rzecznik ubezpieczeniowy, instytucja powołana w 2003 r.; wybierany przez Prezesa Rady Ministrów, na wniosek Ministra Finansów), Główny Rzecznik Dyscypliny Finansów Publicznych (ustanowiony w 2004 r., wybierany przez Prezesa Rady Ministrów, na wniosek ministra właściwego do spraw finansów publicznych), Rzecznik Praw Pacjenta Szpitala Psychiatrycznego (instytucja powołana w 2005 r.)., Rzecznik Praw Pacjenta (ustanowiony w 2009 r., wybierany przez Prezesa Rady Ministrów), Rzecznik Małych i Średnich Przedsiębiorców (ustanowiony w 2018 r., wybierany przez Prezesa Rady Ministrów, na wniosek ministra właściwego do spraw gospodarki).

Projekt ustawy o RPP jest częścią zbioru ustaw mających zastąpić obecnie obowiązującą ustawę z dnia 29 sierpnia 1997 r. - Ordynacja podatkowa $^{8}$.

Wejście w życie nowej regulacji wraz z nową Ordynacją podatkową ma zagwarantować prawa podatnikom i wzmocnić ich poziom bezpieczeństwa w relacjach z organami Krajowej Administracji Skarbowej (dalej: KAS) ${ }^{9}$. Głównym celem RPP będzie dbanie o interesy ogółu oraz

7 Ustawa z dnia 15 lipca 1987 r. o Rzeczniku Praw Obywatelskich (tekst jedn. Dz.U. z 2020 r. poz. 627).

8 Rządowy projekt ustawy Ordynacja Podatkowa, VIII kadencja, nr projektu: UD409, bip.kprm.gov.pl, (dostęp: 8.04.2019 r.).

9 Krajowa Administracja Skarbowa - organ łączący administrację skarbową, kontrolę skarbową oraz służbę celną, funkcjonujący w Polsce od 1 marca 2017 r. 
osiągnięcie pozytywnych rezultatów spraw wszystkich podatników, a nie tylko wybranej grupy. Nowa instytucja ma również pomóc właścicielom firm w poruszaniu się $\mathrm{w}$ gąszczu przepisów podatkowych. Przejawem tego będzie zwiększenie zaangażowania przedsiębiorców w działalność gospodarczą przy równoczesnym zmniejszeniu spraw administracyjnych. Do RPP będą zgłaszać się podatnicy ${ }^{10}$, których nie stać na profesjonalną pomoc doradcy podatkowego.

Jak obrazuje tabela nr 1, ustanowienie specjalistycznej instytucji RPP - jest stosunkowo dobrze ugruntowane w innych państwach, m.in. w Kanadzie (Taxpayer's Ombudsman), RPA (Tax Ombudsman), Meksyku (Mexican Tax Ombudsman), Pakistanie (Federal Ombudsman), Australii (od 2016 r.), Włoszech, Gruzji czy na Ukrainie ${ }^{11}$. Przykładowo w Kanadzie w roku budżetowym 2017-2018 urząd RPP rozwiązał 2522 sprawy ${ }^{12}$, w RPA w tym samym roku rozwiązano 1404 sprawy $^{13}$, zaś w Australii 2055 spraw $^{14}$. Należy zwrócić uwagę, iż rządy w jedenastu krajach świata ustanowiły niezależny organ zajmujących się zagadnieniami dotyczącymi kwestii skarg podatkowych, np. tax ombudsman lub podobną instytucję. Przykładowo w Belgii nazwana jest ona mediatorem podatkowym, we Francji mediatorem, w Japonii po prostu pomocą podatkową.

10 Podatnik - zgodnie z polskim prawem jest nim osoba fizyczna, osoba prawna lub jednostka organizacyjna niemająca osobowości prawnej, podlegająca na mocy ustaw podatkowych obowiązkowi podatkowemu. Działalność RPP dedykowana jest głównie osobom fizycznym.

11 Zespół wGospodarce, Podatnicy będq mieli swojego Rzecznika, Warszawa 2018, https://wgospodarce.pl/informacje/52869-podatnicy-beda-mieli-swojego-rzecznika (dostęp: 2.01.2021 r.).

12 Office of the Taxpayers' Ombudsman, Annual Report 2017-2018, Kanada 2018, s. 15.

13 Office of the Tax Ombud, Tax Ombud Annual Report 2017/18, RPA 2018, s. 1.

14 Taxation Ombudsman, Annual Reports, http://igt.gov.au/publications/annual-reports/ annual-report-2017-18/performance-report/ (dostęp: 2.01.2019 r.). 
Tabela 1. Specjalne urzędy ustanowione w celu rozpatrywania skarg podatników.

\begin{tabular}{|l|c|c|c|c|c|}
\hline Państwo & $\begin{array}{c}\text { Czy } \\
\text { funkcjonuje } \\
\text { organ } \\
\text { specjalny }\end{array}$ & $\begin{array}{c}\text { Szczególne } \\
\text { ramy prawne }\end{array}$ & $\begin{array}{c}\text { Autonomiczny } \\
\text { od organu } \\
\text { dochodowego }\end{array}$ & $\begin{array}{c}\text { Raport } \\
\text { o problemach } \\
\text { systemowych }\end{array}$ & Nazwa organu \\
\hline Austria & Tak & Tak & Tak & Tak & $\begin{array}{c}\text { obsługa } \\
\text { rzecznika } \\
\text { podatnika }\end{array}$ \\
\hline Belgia & Tak & Tak & Tak & Tak & $\begin{array}{c}\text { mediator } \\
\text { podatkowy }\end{array}$ \\
\hline Francja & Tak & Tak & Tak & Nie & $\begin{array}{c}\text { Republiki / } \\
\text { regionu }\end{array}$ \\
\hline Niemcy & Nie & Nie & Nie & Nie & Tak \\
\hline Korea & Tak & Tak & Nie & adwokat \\
podatnika
\end{tabular}

Źródło: Tax Administration, Comparative information on OECD and other advanced and emerging economics, OECD 2013, s. 47.

\section{Kompetencje Rzecznika Praw Podatnika}

Nowy organ z założenia ma wspierać podatników w sporze z organem podatkowym. Zakres jego działań będzie obejmował zatem udział w toczących się postępowaniach, możliwość wglądu do akt ${ }^{15}$ oraz przedstawienie wniosku do władz skarbowych w trakcie toczącego się postępowania. W zakresie funkcji interwencyjnej RPP ma zostać wyposażony w uprawnienie do zwracania się o wszczęcie postępowania podatkowego, wniesienia i odwołania skargi do sądu administracyjnego, w tym skargi kasacyjnej do Naczelnego Sądu Administracyjnego, wniesienie skargi o stwierdzenie niezgodności z prawem prawomocnego orzeczenia, a także będzie mógł uczestniczyć w postępowaniu przed organami administracji

15 Naczelny Sąd Administracyjny dostrzega tutaj problem podważenia zaufania do sędziów i ich niezależności. 
publicznej lub sądami na prawach przysługujących prokuratorowi. Nowa instytucja otrzyma zadanie wspierania obywateli, którzy nie mają możliwości bądź wiedzy, jak wystąpić do właściwego dla nich organu z wnioskiem o indywidualną interpretację podatkową. RPP będzie uprawniony, aby złożyć wniosek do NSA o wyjaśnienie i interpretację przepisów wywołujących rozbieżności w orzecznictwie, wystąpić w imieniu podatnika do właściwych organów z wnioskiem o wstrzymanie czynności bądź postępowania egzekucyjnego dotyczącego podatnika. Kluczową kompetencją będzie możliwość wystąpienia (na wniosek podatnika) do Ministra Finansów w celu zmiany decyzji ostatecznej bądź wydania decyzji uchylającej na podstawie nowej Ordynacji podatkowej ${ }^{16}$. Ustawodawca zakłada również, że RPP będzie występował do innych organów administracji publicznej w celu zmiany aktów normatywnych dotyczących spraw podatkowych oraz wszczęcia inicjatywy ustawodawczej. Należy zwrócić uwagę, iż RPP będzie miał możliwość wystąpić do Ministra Finansów z wnioskiem o interpretację podatkową oraz z wnioskiem o wydanie tzw. ogólnych objaśnień podatkowych w sprawach budzących wątpliwości interpretacyjne lub jeżeli spowoduje to znaczące zmniejszenie liczby wniosków o wydanie interpretacji podatkowych ${ }^{17}$. Ustawa reguluje ponadto uprawnienie RPP do interwencji w przypadku stwierdzenia naruszenia praw podatnika przez organ. Zakres jego kompetencji obejmuje również informowanie Ministra Finansów o dostrzeżonych barierach dla podatników.

Istotnym zadaniem RPP będzie bieżąca analiza prawa podatkowego, co wiąże się z opiniowaniem projektów dotyczących planowanych reform podatków przedstawionych przez Ministerstwo Finansów oraz sygnalizowanie zmian w zakresie stosowania prawa podatkowego. Jednym z głównych zadań RPP będzie wnoszenie zastrzeżeń do projektów aktów normatywnych z zakresu prawa podatkowego - w szczególności analiza interpretacji ogólnych i indywidualnych dotyczących nowej Ordynacji podat-

16 Rządowy projekt ustawy o Rzeczniku Praw Podatnika, VIII kadencja, nr projektu: UD421, bip.kprm.gov.pl, (dostęp: 8.04.2019 r.).

17 Kancelaria Prezesa Rady Ministrów, Wykaz prac legislacyjnych i programowych Rady Ministrów: Projekt ustawy o Rzeczniku Praw Podatnika, Warszawa 2019, s. 1. 
kowej. Zakres jego obowiązków obejmować będzie również analizę załatwiania przez organy skarbowe skarg i wniosków. RPP będzie uprawniony do przedstawiania organom, organizacjom i instytucjom publicznym rekomendacji $\mathrm{w}$ zakresie polepszenia spójności prawa podatkowego i zapewnienia lepszej ochrony praw podatnika oraz usunięcia zbędnych procedur czy też wymogów formalnych. RPP będzie ponadto analizować orzeczenia sądów administracyjnych oraz innych sądów i trybunałów w sposób, w jaki wpływają na decyzje dotyczące spraw podatkowych. Minister Finansów zakłada w swoim projekcie, że RPP będzie uprawniony raz do roku wydawać zbiór interpretacji indywidualnych oraz orzeczeń sądów administracyjnych oraz będzie wyznaczał w nim dominującą wykładnię, co jest niewątpliwie jedną z największych zalet nowej instytucji, uprawniającą podatników do powołania się na tzw. utrwaloną praktykę interpretacyjną i klauzulę ochrony podatnika ${ }^{18}$. Obecnie kompetencja wydawania interpretacji prawnych jest niezgodna $\mathrm{z}$ art. 33 ust. 1 ustawy Prawo przedsiębiorców ${ }^{19}$, który zakłada, iż „właściwi ministrowie oraz organy, które na podstawie odrębnych przepisów są upoważnione do opracowywania i przedkładania Radzie Ministrów projektów aktów prawnych, dążą do zapewnienia jednolitego stosowania przepisów prawa z zakresu działalności gospodarczej, w szczególności wydając, w zakresie swojej właściwości, z urzędu lub na wniosek Rzecznika Małych i Średnich Przedsiębiorców wyjaśnienia przepisów regulujących podejmowanie, wykonywanie lub zakończenie działalności gospodarczej, dotyczące praktycznego ich stosowania (objaśnienia prawne), przy uwzględnieniu w szczególności orzecznictwa sądów, Trybunału Konstytucyjnego i Trybunału Sprawiedliwości Unii Europejskiej”. A zatem, jak wynika z ustawy Prawo przedsiębiorców, organem posiadającym inicjatywę ustawodawczą przedkładania Radzie Ministrów projektów aktów prawnych jest Minister Finansów. De lege ferenda będzie to wymagało, aby ustawa o RPP nie stała w sprzeczności z ustawą Prawo przedsiębiorców.

18 Rządowy projekt ustawy o Rzeczniku Praw Podatnika, VIII kadencja, nr projektu: UD421, bip.kprm.gov.pl, (dostęp: 8.04.2019 r.).

19 Ustawa z dnia 6 marca 2018 r. (tekst jedn. Dz.U. z 2021 r., poz. 162), dalej: Prawo przedsiębiorców. 
RPP odpowiedzialny będzie również za prowadzenie działalności informacyjnej i edukacyjnej z zakresu prawa podatkowego.

W zakresie swych kompetencji RPP powinien reagować na naruszanie praw podatnika oraz interweniować na etapie konfliktu z urzędem skarbowym. RPP będzie uprawniony do wszczynania postępowania podatkowego oraz wnoszenia skargi do sądu administracyjnego o stwierdzenie niezgodności z prawem prawomocnego orzeczenia i wnoszenia skargi kasacyjnej do NSA. RPP miałby zostać wyposażony w kompetencje prokuratora w postępowaniach toczących się przed sądami bądź przed organami administracji publicznej.

Ponadto zadaniem RPP będzie prowadzenie przewidzianej w projekcie nowej Ordynacji podatkowej procedury mediacyjnej oraz kierowanie do RPO wniosków o występowanie przezeń do TK w kwestiach dotyczących praw podatnika. Nowe kompetencje przyczynią się do wzmożonej współpracy nie tylko z RPO, ale również z Rzecznikiem Małych i Średnich Przedsiębiorców, sprzyjając zwiększeniu poczucia bezpieczeństwa w zakresie prowadzenia działalności gospodarczej. RPP będzie współdziałał z fundacjami, stowarzyszeniami, zrzeszeniami, samorządami zawodowymi, ruchami obywatelskimi, organizacjami zajmującymi się reprezentacją podatników w kraju i za granicą oraz z organizacjami monitorującymi jakość prawa podatkowego i kierunki jego reform.

RPP będzie podmiotem administracji publicznej, powoływanym przez Prezesa Rady Ministrów na wniosek Ministra Finansów. Jego kadencja miałaby trwać 6 lat. W tym kontekście należy domniemywać, że ma to sprzyjać niezależności RPP jako organu, który będzie sprawował swą funkcję mimo zmiany ekipy rządzącej. Głównym założeniem nowej instytucji jest jej niezależny charakter. Ustawodawca określił, iż RPP ma być wyłaniany $\mathrm{w}$ drodze konkursu, tzn. według zasady niezależnego i otwartego naboru. Zakłada się, że będzie powoływany tylko na jedną kadencję, bez możliwości jej przedłużenia. Dodatkowo projektodawca przewidział zamknięty i surowy katalog przesłanek odwołania osoby peł- 
niącej funkcję RPP ${ }^{20}$. Przykładowo RPP będzie mógł zostać odwołany w przypadku utraty nieposzlakowanej opinii, dającej rękojmię prawidłowego wykonywania powierzonych obowiązków ${ }^{21}$. Kandydat powinien posiadać stopień doktora z zakresu prawa lub ekonomii oraz wykazać się dziesięcioletnim udokumentowanym doświadczeniem praktycznym z zakresu prawa podatkowego. Ponadto RPP nie może należeć do partii politycznej, związku zawodowego ani prowadzić działalności zarówno gospodarczej, jak i publicznej niedającej pogodzić się z godnością urzędu. Wyjątkiem od tej reguły jest możliwość łączenia funkcji RPP ze stanowiskiem naukowo-dydaktycznym lub naukowym w szkole wyższej lub w innej jednostce naukowej. Wśród pozostałych wymagań znalazły się powszechne kryteria dotyczące sprawowania wyższych stanowisk kierowniczych w administracji publicznej: konieczność posiadania obywatelstwa polskiego, korzystanie z pełni praw publicznych, legitymowanie się niekaralnością w zakresie przestępstwa umyślnego, posiadanie nieposzlakowanej opinii oraz niepełnienie służby zawodowej ani żadnej innej funkcji, np. na zasadach stosunku pracy, w organach bezpieczeństwa państwa wymienionych w art. 2 ustawy z dnia 18 października 2006 r. $^{22}$ Zastępcy RPP będą musieli wykazać się pięcioletnim udokumentowanym doświadczeniem z zakresu prawa podatkowego oraz posiadać tytuł zawodowy magistra prawa lub ekonomii. Podjęcie czynności przez Rzecznika następować będzie z urzędu lub na wniosek. RPP będzie realizował swoje zadania przy pomocy Biura RPP. RPP będzie posiadał szesnastu zastępców (również wybieranych na sześcioletnią kadencję, w drodze otwartego konkursu) i trzydziestu dwóch przedstawicieli terenowych. Zastępca rzecznika oraz dwaj przedstawiciele terenowi będą tworzyć w każdym województwie trzyosobowe zespoły eksperckie, będą powoływani na

20 Kancelaria Prezesa Rady Ministrów, Wykaz prac legislacyjnych i programowych Rady Ministrów: Projekt ustawy o Rzeczniku Praw Podatnika, Warszawa 2019, s. 1.

21 Konfederacja Lewiatan, Rzecznik Praw Podatnika będzie zależny od ministra finansów, Warszawa 2018, s. 1, https://www.pit.pl/aktualnosci/rzecznik-praw-podatnika-bedziezalezny-od-mf-to-niedobrze-937355, (dostęp: 2.01.2021 r.).

22 Ustawa z dnia 18 października 2006r. o ujawnieniu informacji o dokumentach organów bezpieczeństwa państwa z lat 1944-1990 oraz treści tych dokumentów (tekst jedn. Dz.U. z 2016 r., poz. 1721 ze zm.) 
wniosek RPP przez Ministra Finansów. Rzecznik Praw Podatnika oraz jego Biuro będą funkcjonować jako państwowa jednostka budżetowa w rozumieniu ustawy z 27 sierpnia 2009 r. o finansach publicznych ${ }^{23}$.

\section{Rozważania na temat zasadności powołania Rzecznika Praw Podatnika}

Głównym celem ustanowienia w polskim systemie prawnym RPP jest zapewnienie efektywnej ochrony słabszej stronie stosunku podatkowego. Dlatego tak ważne jest, aby był to niezależny organ. Zakłada się, że RPP wyłaniany będzie w drodze otwartego konkursu, prowadzącego do wskazania dwóch najlepszych kandydatów. Spośród nich Minister Finansów ma wybrać jednego i zarekomendować go Prezesowi Rady Ministrów ${ }^{24}$. Przedmiotowa ustawa reguluje także sposób odwoływania RPP przez Ministra Finansów. W projekcie ustawy zapisano kryterium posiadania doświadczenia $\mathrm{w}$ administracji publicznej, nie przewidziano jednak przerwy między pracą w urzędzie a objęciem stanowiska rzecznika. Zagadnienie to wydaje się dość problematyczne, gdyż stanowisko RPP może objąć osoba obecnie piastująca stanowisko dyrektora Izby Administracji Skarbowej. Po drugie, szacuje się, że w przyszłości roczny koszt utrzymania jego urzędu wraz $\mathrm{z}$ szesnastoma zastępcami i trzydziestoma dwoma przedstawicielami terenowymi to wydatek rzędu od 21 do $24 \mathrm{mln} \mathrm{z}^{25}$. Jest to dużo bardziej rozbudowana struktura biurokratyczna w porównaniu do innych istniejących urzędów rzeczników, w tym rzeczników wymienionych w Konstytucji RP.

Po lekturze rządowego projektu ustawy można odnieść wrażenie, że kompetencje Rzecznika Finansowego, Rzecznika Małych i Średnich Przedsiębiorców oraz RPO będą się istotnie przenikały. Najwięcej pro-

23 Kancelaria Prezesa Rady Ministrów, Wykaz prac legislacyjnych i programowych Rady Ministrów: Projekt ustawy o Rzeczniku Praw Podatnika, Warszawa 2019, s. 1.

24 Konfederacja Lewiatan, Rzecznik Praw Podatnika - potrzebna instytucja, Warszawa 2018, https://ksiegowosc.infor.pl/wiadomosci/2772114,Rzecznik-Praw-Podatnikapotrzebna-instytucja.html (dostęp: 2.01.2020 r.).

25 Rządowy projekt ustawy o Rzeczniku Praw Podatnika, VIII kadencja, nr projektu: UD421, bip.kprm.gov.pl (dostęp: 8.04.2019 r.). 
blemów z kwestiami podatkowymi mają przedsiębiorcy, jednak nie należy przekazywać kompetencji RPP Rzecznikowi Małych i Średnich Przedsiębiorców, gdyż osoby fizyczne orz przedsiębiorcy inni niż mali i średni, nie zostaliby objęci systemem ochrony ${ }^{26}$. Zasadnym wydaje się powierzenie kompetencji RPP w ręce RPO, który posiada uprawnienia występowania do TK, jest instytucją w pełni niezależną oraz wykazał się już skutecznością, m.in. w przypadku stosowania zerowej stawki VAT na inwestycje związane z ochroną brzegów morskich. Ponadto należy zauważyć, że RPP ma posiadać uprawnienie wyłącznie pośredniczące, gdy chodzi o możliwość działania przed TK, występując z wnioskiem do RPO. Wynika z tego, że dwa organy będą sprawowały nadzór nad tą samą materią spraw, tylko na innych poziomach postępowania, co może prowadzić do niepożądanego efektu. Co w przypadku, kiedy RPO będzie miał odmienne od RPP zdanie w aspekcie wniosku? W świetle powyższych rozważań nasuwa się pytanie: czy RPP będzie strażnikiem dobra wspólnego? Czy instytucja ta będzie w rzeczywistości stała na straży dobra wspólnego pojmowanego jako suma działań umożliwiających i ułatwiających rozwój wspólnoty wszystkich podmiotów obrotu gospodarczego będących jednocześnie podatnikami?

Aby zapewnić wszystkim obywatelom łatwy dostęp, Rzecznik Praw Podatnika będzie posiadał swoich zastępców w każdym województwie. Kolejną cechą wpisującą się w realizację zasady dobra wspólnego jest powszechność i bezwarunkowa dostępność. Płacenie podatków obowiązuje każdego obywatela i dlatego RPP ma być instytucją dedykowaną nie tylko przedsiębiorcom czy osobom zamożnym, ale posiadać będzie charakter powszechny, czyli dla ogółu społeczeństwa. Przypomnijmy, że RPP formułować będzie opinie i wnioski dotyczące sposobu załatwiania sprawy oraz zostanie upoważniony do poinformowania szefa KAS o ewentualnym niedopełnieniu obowiązków służbowych, co z kolei może wiązać się z pociągnięciem do odpowiedzialności dyscyplinarnej. Z pewnością

26 Konfederacja Lewiatan, Rzecznik Praw Podatnika-potrzebna instytucja, Warszawa 2018, https://ksiegowosc.infor.pl/wiadomosci/2772114,Rzecznik-Praw-Podatnikapotrzebna-instytucja.html, (dostęp: 2.01.2020 r.). 
fakt ten wpłynie na zmianę praktyki urzędniczej na bardziej przychylną w stosunku do podatników.

\section{Wnioski}

Ochrona praw podatnika nabiera szczególnego znaczenia wobec nawarstwiania się coraz bardziej skomplikowanych przepisów podatkowych. Regulacje nowej Ordynacji podatkowej zakładają zachowanie równowagi pomiędzy organem administracji podatkowej a podatnikiem. Przedstawiony projekt ustawy o RPP przeszedł rządowy etap procesu legislacyjnego (nr projektu UD421) i został przyjęty przez Radę Ministrów 28 maja 2019 r. $^{27}$, a następnie wpłynął do Sejmu 4 czerwca 2019 r. (druk nr 3516), skąd został skierowany do I czytania na posiedzeniu Sejmu. Pierwsze czytanie projektu nastąpiło na 83. posiedzeniu Sejmu, następnie projekt ustawy o RPP został skierowany do Komisji Finansów Publicznych ${ }^{28}$. Tam zaś, wraz z projektem ustawy Ordynacja podatkowa (druk 3517) oraz przepisów wprowadzających ustawę - Ordynacja Podatkowa i ustawę o Rzeczniku Praw Podatnika (druk nr 3518), projekt ustawy o RPP skończył swój bieg, a do projektu ustawy w takim czy innym brzmieniu nigdy nie powrócono ${ }^{29}$.

Nasuwa się zatem pytanie, czy słusznie postąpiono, rezygnując z wprowadzenia do polskiego porządku prawnego instytucji RPP. Jednym z głównych założeń tej instytucji jest bowiem złagodzenie nadmiernego formalizmu oraz walka z działaniami podejmowanymi na niekorzyść podatnika. Zamierzano wprowadzić w tym obszarze specjalne mechanizmy, mające chronić podatnika w kontaktach z KAS. Pomysł powołania RPP, który opiniowałby projekty reform podatkowych MF i konsultował je

27 Rządowy projekt ustawy o Rzeczniku Praw Podatnika, VIII kadencja, nr projektu: UD421, bip.kprm.gov.pl, (dostęp: 3.01.2021 r.). Zakładano, że projektowane regulacje wejdą w życie w roku 2020.

28 Sejm RP, Rzq̨dowy projekt ustawy o Rzeczniku Praw Podatnika, http://www.sejm.gov.pl/ sejm8.nsf/PrzebiegProc.xsp?id=3C4188DE6229EA53C1258417003990CA (dostęp: 3.01.2021 r.).

29 Sejm RP, ITV Sejm - lipiec, http://sejm.pl/Sejm8.nsf/transmisje_arch.xsp?page=12\&unid= 440E8795B4A5590AC1257FF4004EEFC2 (dostęp: 3.01.2021 r.). 
z urzędnikami, wydawał się rozwiązaniem bardzo efektywnym. RPP byłby swoistą przeciwwagą dla administracji skarbowej, osobą, która krytycznie patrzyłaby na pracę MF, ale również udzielała wskazówek, co do pożądanych kierunków zmian. Miękkie formy zarządzania, jak np. procedura mediacyjna między KAS a podatnikiem, z pewnością odciążyłaby sądy administracyjne. Instytucja RPP mogłaby przyczynić się do polepszenia jakości polskiego prawa podatkowego oraz ujednolicenia jego stosowania. Raporty sporządzane przez RPP mogłyby okazać się szczególnie pomocne dla Ministra Finansów i Szefa KAS przy podejmowaniu działań zmierzających do zmiany przepisów ${ }^{30}$.

Analiza danych dotyczących funkcjonowania sądów administracyjnych przemawia za utworzeniem dodatkowej instytucji specjalizującej się w zagadnieniach podatkowych. Niemalże 30\% skarg wpływających do sądów administracyjnych dotyczy kwestii podatkowych oraz egzekucji świadczeń pieniężnych. Skalę problemów związanych ze stosowaniem przepisów prawa podatkowego w naszym kraju obrazują następujące dane: w 2017 roku do wojewódzkich sądów administracyjnych wpłynęło w tym zakresie 18849 skarg (na 72426 skarg ogółem). W tym samym czasie do NSA wpłynęło 6765 skarg kasacyjnych dotyczących spraw podatkowych (na 17746 skarg ogółem) ${ }^{31}$. Ostatnie kilka lat wskazuje również na tendencję rosnącą, jeśli chodzi o liczbę zgłoszonych do RPO skarg sądowo-administracyjnych na rozstrzygnięcia organów podatkowych. Liczba jego wystąpień i interwencji w indywidualnych sprawach prowadzonych przez organy podatkowe rośnie co roku i w 2017 roku wyniosła 24 wystąpienia i interwencje. Była to i tak nieadekwatna liczba w stosunku do zapotrzebowania i olbrzymiej liczby wnoszonych skarg.

Ministerstwo Finansów zdawało się dostrzegać, jak ogromny ciężar dla podatników stanowi stosowanie materialnego prawa podatkowego. Rzecznik Praw Podatnika miał stanowić dla nich wsparcie. RPP powinien jednak być wybierany i odwoływany przez bardziej neutralny organ pań-

30 Ministerstwo Finansów, Uzasadnienie ustawy o Rzeczniku Praw Podatnika, Warszawa 2018, s. 3.

31 NSA, Informacja o działalności sq̨dów administracyjnych w 2017 roku, Warszawa 2017, s. 371, 390, 396, 409. 
stwa, jak np. Prezydent RP czy Sejm RP. Musiałby być ponadto bezstronną instytucją, niepodlegającą Ministrowi Finansów. W świetle projektowanych postanowień, RPP miał posiadać szerokie umocowanie w zakresie spraw podatkowych, i to na dwóch płaszczyznach: ustawodawczej oraz wykonawczej. Jednakże część tych umocowań nie byłaby niezależna i wolna od działania innych organów, takich jak MF czy sądy administracyjne, a nawet RPO. Praktycznie większość czynności RPP będzie wymagała niejako potwierdzenia ze strony innych organów, aby faktycznie można było mówić o skutecznej pracy jego urzędu. Roczny koszt utrzymania RPP wraz z biurem to wydatek rzędu ok. 20 mln zł. To z jednej strony duży wydatek dla podatników, jednak z drugiej strony koszt ten rozkłada się na wynagrodzenie RPP i jego zastępców, przedstawicieli terenowych oraz koszty funkcjonowania biura. Rodzi to obawy, iż skalkulowany na tym poziomie budżet instytucji nie pozwoliłby na zaoferowanie specjalistom i doradcom podatkowym wchodzącym w skład biura płac zbliżonych do ofert rynkowych. W tej sytuacji, organ powołany do realizacji zadań wymagających najwyższych umiejętności i profesjonalnej wiedzy mógłby nie dysponować wystarczająco wykwalifikowaną kadrą i tym samym nie byłby w stanie sprostać obowiązkom ze względu na niedoszacowane koszty jego działalności.

Projekt ustawy o RPP podzielił świat nauki. Zdaniem Adama Mariańskiego z Uniwersytetu Łódzkiego instytucja RPP jest potrzebna, powinien on jednak stanowić wyspecjalizowaną komórkę w ramach struktury urzędu $\mathrm{RPO}^{32}$. Podobne stanowisko przedstawił Maciej Tarasek w artykule pt. „Rzecznik praw podatnika - czy rozwiq̨że problemy polskiego podatnika": RPO posiada odpowiednie instrumenty umożliwiające mu skuteczne reagowanie, jednak nie są one efektywnie wykorzystywane ${ }^{33}$. Z kolei Mateusz Pach z Wydziału Prawa, Administracji i Ekonomii Uni-

32 K. Kosilicki, Specjalny Rzecznik ma pomóc podatnikom, Warszawa 2018, www.prawo.pl/podatki/rzecznik-praw-podatnika-zacznie-dzialac-od-2020-roku,289595.html (dostęp: 3.01.2021 r.).

33 M. Tarasek, Rzecznik praw podatnika - czy rozwiq̨że problemy polskiego podatnika?, „Białostockie Studia Prawnicze” 2013, z. 13, s. 181. 
wersytetu Wrocławskiego uważa, iż instytucja RPP w znaczący sposób mogłaby poprawić funkcjonowanie krajowego systemu podatkowego ${ }^{34}$.

Podsumowując powyższe rozważania, można przyjąć, że RPP nie jest potrzebny jako odrębna od RPO instytucja. Należałoby rozszerzyć kompetencje RPO oraz odpowiednio zwiększyć jego budżet, celem umożliwienia realizacji dodatkowych uprawnień. Ponadto należałoby zadbać, aby kompetencje poszczególnych rzeczników nie nakładały się na siebie, co prowadziłoby do powstawania sporów kompetencyjnych. Spory takie będzie musiał rozstrzygać niezależny sąd, a przecież urząd rzecznika miałby efektywnie służyć obywatelom, a nie dokładać nowych problemów. Istotnym mankamentem przedstawionej regulacji było to, iż RPP nie byłby podmiotem uprawnionym do wnoszenia projektów ustaw, a zatem na gruncie art. 33 Prawa przedsiębiorców, nie byłby on uprawniony do wydawania opinii prawnych oraz interpretacji indywidualnych w sprawach podatkowych. Takie uprawnienie będzie miał wyłącznie MF. Zadania z tym związane staną się wówczas niewykonalne. Ponadto łączenie RPP i RPO w zakresie występowania do TK w sprawach podatkowych, kreuje problem odnośnie kompetencji do określenia przedmiotu zagadnienia, jakie miałby rozstrzygnąć TK. Jeżeli wnioskodawcą byłby de facto RPO, to rodzi się pytanie, czy to nie on ostatecznie decydowałby o sposobie przedstawienia problemu. Projekt ustawy nie rozwiązywał tej kwestii. Ponadto, powoływanie kolejnych instytucji rzeczników rodzi również obawę o to, że aparat państwowy zaczyna „obudowywać” władzę sądowniczą podmiotami, które mogłyby ingerować w działania niezależnych sądów i wpływać na kierunki ich linii orzeczniczej.

\section{Bibliografia:}

Pach M., Zasady ochrony podatnika w prawie podatkowym, „Przegląd Prawniczy ELSA Poland” 2013, z. 1, s. 193-204.

Tarasek M., Rzecznik praw podatnika - czy rozwiq̨że problemy polskiego podatnika?, „Białostockie Studia Prawnicze” 2013, z. 13, s.175-186.

34 M. Pach, Zasady ochrony podatnika w prawie podatkowym, „Przegląd Prawniczy ELSA Poland” 2013, z. 1, s. 194. 